資料

\title{
食料中の供給脂質の動向 (2)
}

\author{
長 倉 稔・吉 富 和 彦 \\ 日清製油株式会社（广104 東京都中央区新川 1-23-1）
}

Trend on Supply of Fats and Oils in Foods (2)

Minoru Nagakura and Kazuhiko Yoshitomi

The Nissihn Oil Mills, Ltd. (23-1, Shinkawa 1-Chome, Chuo-ku, Tokyo)

\section{1 はじめに}

最近リノール酸の摂取量が多くなってきており,リノ レン酸の捸取量が相対的に少なくなっているので, 成人 病䂆方上リノレン酸の摂取量を増した方がよいとの説が ある

先に食料需給表 (農林水産省編) から三訂日本食品標 準成分表（科学技術庁編）に基づいて 1981 年までの食 料中の供給脂質の動向について報告したが2)，1965 年以 降のデータについて四訂日本食品標準成分表（科学技術 庁編）に基づく食料需給表 ${ }^{3)}$ が発表されたので，それに より 1984 年までの食料中の供給脂質の動向について再 度検討した。

\section{2 供給脂質の動向}

食品群別供給脂質 ${ }^{3)}$ 及び油脂種類別(供給脂質 ${ }^{4), 5)}$ の推 移を表-1, 2 に示す。表-2 の硬化油については食用加 工油脂の硬化油から推定したものである。

供給脂質の構成比の推移は図-1に示すとおりである。 植物性食品では, 穀類が減少し植物油脂が増加してい る。動物性食品では肉類が増加傾向にある。全般的にみ て, 植物性食品からと動物性食品からとの脂質の割合は

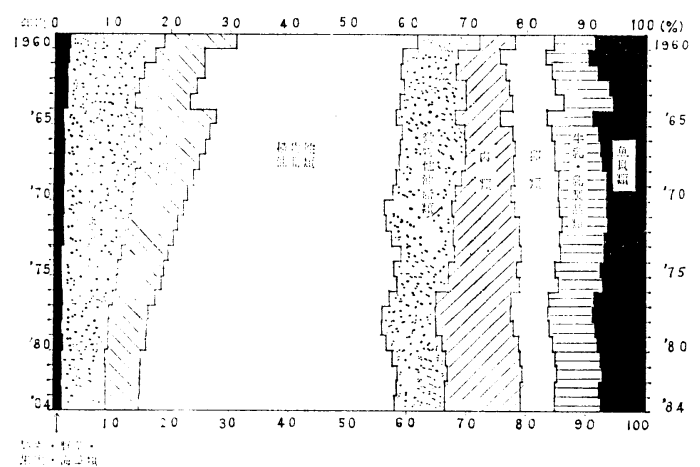

図-1 供給脂質の構成比の推移
ほぼ $58: 42$ であまり変化していない。

供給栄養素の推移を 表-3 に, 供給脂質エネルギー比 率を 図-2 に示す。供給脂質エネルギー比率は増加傾向 にあり, 現在 $28.7 \%$ に達しているが, 厚生省の栄養所 要量 ${ }^{6)}$ では脂肪エネルギー比は $20 \sim 30 \%$ となっており, その範囲内にある。

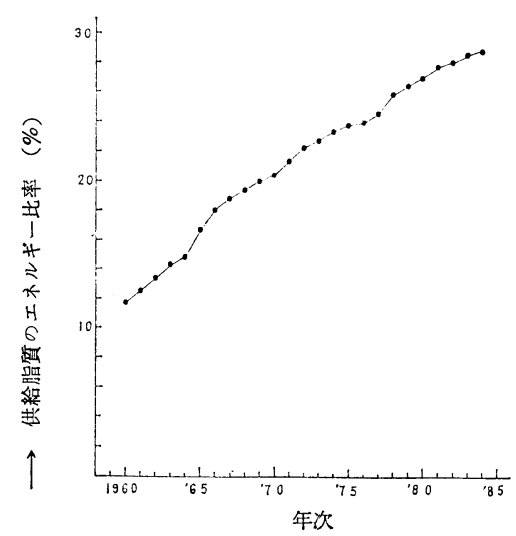

図-2 供給脂質のエネルギー比率の推移

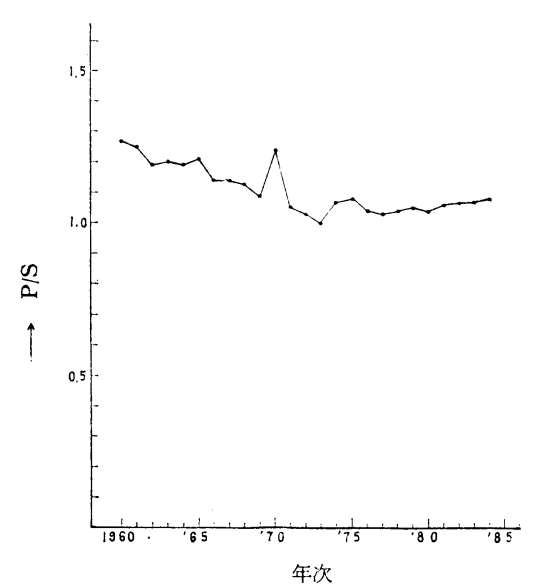

図-3 供給脂質の $\mathrm{P} / \mathrm{S}$ 比の推移 
各食品中の脂質の不飽和度別組成を前報と同様に表-4 のように推定し，これに基づいて供給脂質の不飽和度別 組成を求め 表-5 に示した。また多不飽和脂質の不飽和 度別構成比を図-3〜6 亿示した。なお，不飽和度（二重 結合の数）はF值で示してある。

表-1 食品群別国民 1 人 1 日当たり供給脂質 $(\mathrm{g})$

\begin{tabular}{|c|c|c|c|c|c|c|}
\hline 品 & 1960年 & 1965年 & 970年 & 1975年 & 1980年 & 1984年 \\
\hline 1. 植 & 17.8 & 26.0 & 33.0 & 37.4 & 42.7 & 46.9 \\
\hline 1.1 噛 & 3.6 & 5.7 & 5.3 & 5.0 & 4.8 & 4.6 \\
\hline 1.1 .1 米 & 2.5 & 3.9 & 3.4 & 3.1 & 2.8 & 2.7 \\
\hline 1.1 .2 小 & 0.8 & 1.7 & 1.8 & .8 & 1.9 & 1.8 \\
\hline 1.1 .3 とうもろこ & 0.0 & 0.0 & 0.0 & 0.0 & 0.0 & 0.0 \\
\hline 1.1 .4 そ 他 & 0.2 & 0.2 & 0.0 & 0.0 & 0.0 & 0.0 \\
\hline 1.2 い & 0.1 & 0.1 & 0.1 & 0.1 & 0.1 & 0.1 \\
\hline 1.3 豆 & 3.6 & 4.7 & 5.6 & 5.3 & 4.9 & 5.2 \\
\hline 1.3 .1 大 & 2.7 & 2.6 & 3.2 & 3.3 & 3.0 & 3.4 \\
\hline 1.3 .2 そ の 他 & 1.0 & 2.1 & 2.3 & 2.0 & 1.8 & 1.8 \\
\hline 1.4 み & 0.8 & 1.3 & 1.2 & 1.0 & 1.0 & 0.9 \\
\hline 1.5 しょう油 & 0.2 & 0.0 & 0.0 & 0.0 & 0.0 & 0.0 \\
\hline 1.6 野 菜 類 & 0.5 & 0.4 & 0.5 & 0.4 & 0.5 & 0.5 \\
\hline 1.6.1 緑黄色野菜 & 0.1 & 0.0 & 0.1 & 0.0 & 0.0 & 0.1 \\
\hline 1.6 .2 そ の 他 & 0.4 & 0.4 & 0.4 & 0.4 & 0.4 & 0.4 \\
\hline 1.7 果 実 類 & 0.2 & 0.1 & 0.2 & 0.2 & 0.3 & 0.3 \\
\hline 1.7 .1 みかん & 0.0 & 0.0 & 0.0 & 0.0 & 0.0 & 0.0 \\
\hline 1.7 .2 り んご & 1 & .0 & 0.0 & 0 & 0.0 & 0.0 \\
\hline 1.7 .3 そ 他 & 0.1 & 0.1 & 0.1 & 0.1 & 0.2 & 0.3 \\
\hline 1.8 海 草 類 & 0.0 & 0.0 & 0.1 & 0.1 & 0.1 & 0.1 \\
\hline 1.9 油 脂 & 8.8 & 13.6 & 19.9 & 25.2 & 30.8 & 34.9 \\
\hline 1.9.1 大豆 油 & 3.3 & 6.4 & 10.1 & 11.0 & 13.0 & 14.5 \\
\hline 1.9.2なたね油 & 2.7 & 2.2 & 3.1 & 7.2 & 8.9 & 11.3 \\
\hline 1.9.3 $し$ 油 & 0.3 & 0.4 & 0.7 & 0.6 & 0.6 & 0.6 \\
\hline 1.9 .4 そ の 他 & 2.6 & 4.7 & 6.0 & .4 & 8.4 & 8.5 \\
\hline 2. 動 物 & 11.1 & 18.8 & 24.2 & 27.4 & 32.8 & 33.9 \\
\hline 2.1 肉 & 1.7 & .4 & 4 & 4 & 9.6 & 10.4 \\
\hline 2.1 .1 牛 & 0.4 & 0.8 & 1.1 & 1.2 & 1.7 & 2.1 \\
\hline 2.1 .2 豚 & 1.0 & 1.6 & 2.9 & 4.1 & 5.4 & 5.5 \\
\hline 2.1 .3 鶏 & 0.1 & 0.5 & .0 & 4 & 2.1 & 2.4 \\
\hline 2.1.4 鯨 & 0.1 & 0.2 & 0.1 & 0.1 & 0.0 & 0.0 \\
\hline 2.1 .5 そ 他 & 0.1 & 0.2 & 0.3 & 0.6 & 0.3 & 0.3 \\
\hline 2.2 卵 & 1.9 & 3.5 & 45 & 4 . & 4.4 & 4.5 \\
\hline 2.3 牛乳及び乳製 & 2.0 & 3.4 & 4.5 & 4.8 & 5.6 & 6.2 \\
\hline 2.4 魚 貝 & 2.5 & 4.0 & 3.9 & 3.0 & 6.1 & 6.0 \\
\hline 2.4 .1 生鮮·冷藏 & 0.0 & 1.6 & 1.4 & 1.9 & 2.4 & 2.5 \\
\hline 2.4 .2 塩 & 2.5 & 2.3 & 2.5 & 2.9 & 3.5 & 3.2 \\
\hline 2.4 .3 缶 & 0.0 & 0.1 & 0.0 & 0.1 & 0.2 & 0.3 \\
\hline 2.5 油 脂 & 3.0 & 4.5 & 5.9 & 6.0 & 7.1 & 6.8 \\
\hline 2.5 .1 魚 - 鯨 油 & 1.1 & 1.1 & 1.8 & 1.7 & 2.5 & 2.5 \\
\hline 2.5 .2 牛 & 0.8 & 1.9 & 2.0 & 1.9 & 1.3 & 1.3 \\
\hline 2.5 .3 そ 他 & 1.2 & 1.6 & 2.1 & 2.4 & 3.3 & 3.0 \\
\hline 3. 総 & 29.1 & 44.7 & 57.0 & 64.9 & 75.3 & 80.7 \\
\hline
\end{tabular}

（注） 1965 年以降は「四訂日本食品標準成分表」により，そ れ以前は「三訂日本食品標準成分表」（科学技術庁）に よる。
表-2 品種別国民 1 人 1 日当たり供給食用油脂 ( $\mathrm{g}$ )

\begin{tabular}{|c|c|c|c|c|c|c|}
\hline 品 & & & & & & \\
\hline 脂 類 & & & & .2 & 9 & \\
\hline 物 性 & & & & & & \\
\hline 표 & & & & & & \\
\hline 豆 & & 34 & 71 & 37 & & \\
\hline 大豆 油 (硬化) & & 0.06 & 29 & 6 & & \\
\hline た放油采 & & & & & .9 & \\
\hline なたね・からし油 & & 2.20 & 3.10 & 7.09 & .40 & \\
\hline $\begin{array}{c}\text { なたね・功し油 } \\
\text { (硬化) }\end{array}$ & 00 & 0.00 & 0.00 & 0.1 & .50 & \\
\hline 乙 油 系 & & 0.4 & & 0.0 & & \\
\hline や & & 0.22 & 0.62 & .4 & 41 & \\
\hline やし油 (硬化) & & 0.18 & 0.08 & .1 & .1 & \\
\hline 実 & & .26 & .36 & & & \\
\hline 綿 & & 1.19 & .15 & .64 & .90 & \\
\hline 綿 実 油 (硬化) & & 0.07 & .21 & 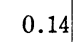 & 0 & \\
\hline フラワー & & 1.05 & 0.24 & 0.1 & .22 & \\
\hline サフラワー & & 1.05 & 0.24 & 1 & .21 & \\
\hline 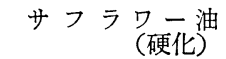 & & 0.00 & 00 & 0.00 & 0.01 & \\
\hline ま & & & 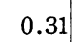 & & & \\
\hline ろこ & & & & & & \\
\hline & & 0.20 & 0.59 & 0.62 & 1.15 & \\
\hline - & 0.00 & 0.00 & 0.00 & 0.0 & 0.1 & \\
\hline
\end{tabular}

\begin{tabular}{lll|l|l|l|l|l|l} 
落 花 生 油 & 0.00 & 0.00 & 0.01 & 0.00 & 0.00 & 0.01
\end{tabular} \begin{tabular}{|l|l|l|l|l|l|l} 
カポック油系 & 0.10 & 0.25 & 0.15 & 0.08 & 0.00 & 0.00
\end{tabular} \begin{tabular}{|l|l|l|l|l|l|l|} 
カポック 油 & 0.10 & 0.20 & 0.12 & 0.06 & 0.00 & 0.00
\end{tabular} \begin{tabular}{|l|l|l|l|l|l|l|} 
カポック油(硬化) & 0.00 & 0.05 & 0.03 & 0.02 & 0.00 & 0.00
\end{tabular} \begin{tabular}{llllll|l|l|l} 
ひまわり 油 & 0.22 & 0.03 & 0.61 & 0.00 & 0.14 & 0.36
\end{tabular}

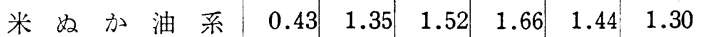
\begin{tabular}{ll|l|l|l|l|l|l} 
米 ぬ か 油 & 0.43 & 1.34 & 1.52 & 1.63 & 1.42 & 1.29
\end{tabular} \begin{tabular}{l|l|l|l|l|l|l|l|} 
米ぬか油 (硬化) & 0.00 & 0.01 & 0.00 & 0.03 & 0.02 & 0.01
\end{tabular} \begin{tabular}{llll|l|l|l|l|l} 
オ & フ & 油 & 0.01 & 0.01 & 0.00 & 0.00 & 0.02 & 0.02
\end{tabular} \begin{tabular}{ll|l|l|l|l|l} 
パーム核油系 & 0.16 & 0.10 & 0.30 & 0.16 & 0.30 & 0.20
\end{tabular} \begin{tabular}{ll|l|l|l|l|l|l} 
パー - 核 油 & 0.12 & 0.05 & 0.25 & 0.00 & 0.13 & 0.01
\end{tabular} \begin{tabular}{|l|l|l|l|l|l|l|} 
パーム核油(硬化) & 0.04 & 0.05 & 0.05 & 0.16 & 0.17 & 0.19
\end{tabular} \begin{tabular}{ll|l|l|l|l|l|l|} 
パーム 油系 & 0.17 & 0.16 & 0.65 & 2.29 & 3.14 & 3.12
\end{tabular} \begin{tabular}{ll|l|l|l|l|l|l|} 
パー 一 油 & 0.16 & 0.14 & 0.60 & 2.10 & 2.77 & 2.70
\end{tabular} \begin{tabular}{|l|l|l|l|l|l|l|} 
パーム油 (硬化) & 0.01 & 0.02 & 0.05 & 0.19 & 0.37 & 0.42 \\
\hline
\end{tabular}

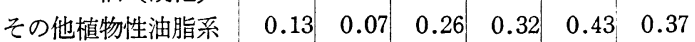
\begin{tabular}{l|l|l|l|l|l|l} 
その他植物性油脂 & 0.11 & 0.04 & 0.16 & 0.23 & 0.32 & 0.27
\end{tabular} \begin{tabular}{l|l|l|l|l|l|l|l|} 
その他植物性油脂 & 0.02 & 0.03 & 0.10 & 0.09 & 0.11 & 0.10
\end{tabular} \begin{tabular}{|ll|l|l|l|l|l|l} 
動 物 性 計 & 3.0 & 4.5 & 5.9 & 6.0 & 7.1 & 6.8
\end{tabular}

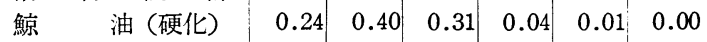

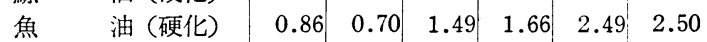
\begin{tabular}{ll|l|l|l|l|l|l|} 
牛 & 脂 系 & 0.8 & 1.9 & 2.0 & 1.9 & 1.3 & 1.3
\end{tabular} \begin{tabular}{ll|l|l|l|l|l|l|}
\hline 牛 & 脂 & 0.73 & 1.73 & 1.88 & 1.66 & 1.05 & 1.02 \\
\hline
\end{tabular}

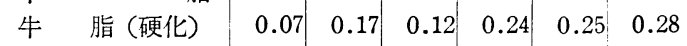
\begin{tabular}{|ll|l|l|l|l|l|l} 
豚 脂 系 & 1.18 & 1.50 & 1.91 & 2.23 & 2.83 & 2.76
\end{tabular} \begin{tabular}{ll|l|l|l|l|l|l|} 
豚 & 脂 & 1.18 & 1.50 & 1.91 & 2.20 & 2.52 & 2.47
\end{tabular}

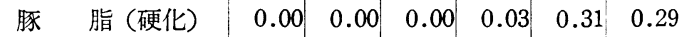
\begin{tabular}{l|l|l|l|l|l|l|} 
その他動物性油脂系 & 0.02 & 0.09 & 0.20 & 0.17 & 0.46 & 0.23
\end{tabular} \begin{tabular}{l|l|l|l|l|l|l|} 
その他動物性油脂 & 0.02 & 0.09 & 0.17 & 0.04 & 0.37 & 0.18
\end{tabular} \begin{tabular}{c|c|c|c|c|c|c}
$\begin{array}{c}\text { その他動物性油脂 } \\
\text { (硬化) }\end{array}$ & 0.00 & 0.00 & 0.03 & 0.13 & 0.09 & 0.05
\end{tabular} 
供給脂質における多不飽和脂肪酸 $(\mathrm{P})$ と飽和脂肪酸 （S）との比（図-3） P/S=1.1/1 でほぼ一定している。

F2 は主としてリノール酸に基づくもので $\omega-6$ 系列 に, F3 は主として $\alpha$-リノレン酸で, ミF5 と同様 $\omega-$ 3 系列に属する。F 4 は $\omega-3$ 系または $\omega-6$ 系として計 算したが, 全体中の F 4 の割合は極めて少ない。最近の $\mathrm{F} 2 / \mathrm{F} 3=7.0$ で，市まり変化がないが 1965 年にはこの F 2/F 3=10 であったので，そのときから時系列的にみ ると,F 2/F 3 の割合はいくらか減少傾向にある。多不飽 和脂肪酸から生合成される各種のプロスタグランジン類

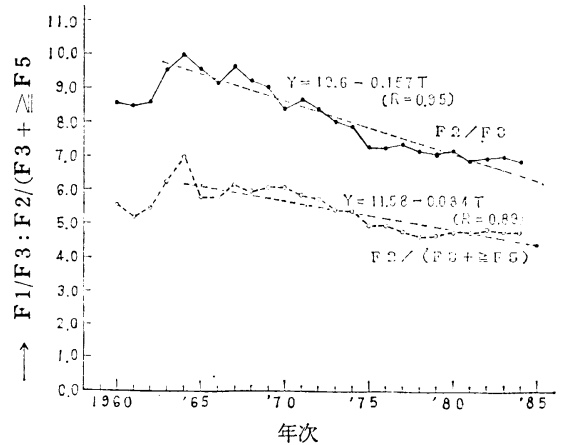

図-4 供給脂質の F $2 / \mathrm{F} 3, \mathrm{~F} 2 /(\mathrm{F} 3+\geqq \mathrm{F} 5 \mathrm{~F})$ の推移 表-3 国民 1 人 1 日当たり供給栄養素の推移

\begin{tabular}{|c|c|c|c|c|c|c|c|}
\hline \multirow[b]{2}{*}{ 年次 } & \multirow{2}{*}{$\begin{array}{c}\text { 熱 量 } \\
\text { (kcal) } \\
\text { a }\end{array}$} & \multicolumn{2}{|c|}{ 脂 } & \multirow{2}{*}{$\begin{array}{l}\text { 質 } \\
\text { エネル } \\
\text { ギー比 } \\
\text { (b/a\%) }\end{array}$} & \multicolumn{3}{|c|}{ タンパク質 } \\
\hline & & (g) & $\begin{array}{c}(\mathrm{kcal}) \\
\mathrm{b}\end{array}$ & & $(g)$ & $\begin{array}{c}(\mathrm{kcal}) \\
\mathrm{c}\end{array}$ & $\begin{array}{l}\text { エネル } \\
\text { ギー比 } \\
(\mathrm{c} / \mathrm{a} \%)\end{array}$ \\
\hline 1960 & $2,290.6$ & 29.1 & 268.6 & 11.7 & 79.2 & 316.8 & 13.8 \\
\hline 1961 & $2,337.7$ & 32.2 & 297.2 & 12.5 & 79.2 & 316.8 & 13.5 \\
\hline 1962 & $2,372.6$ & 34.5 & 318.4 & 13.4 & 80.1 & 320.4 & 13.5 \\
\hline 1963 & $2,384.5$ & 37.0 & 341.5 & 14.3 & 80.0 & 320.0 & 13.4 \\
\hline 1964 & $2,404.4$ & 38.8 & 358.1 & 14.8 & 79.4 & 317.6 & 13.2 \\
\hline 1965 & $2,457.1$ & 44.7 & 412.6 & 16.8 & 74.3 & 297.2 & 12.0 \\
\hline 1966 & $2,478.6$ & 48.5 & 447.7 & 18.0 & 74.9 & 299.6 & 12.0 \\
\hline 1967 & $2,494.8$ & 50.9 & 469.8 & 18.8 & 75.8 & 303.2 & 12.1 \\
\hline 1968 & $2,502.5$ & 52.8 & 487.3 & 19.4 & 76.5 & 306.0 & 12.2 \\
\hline 1969 & $2,502.8$ & 54.5 & 503.0 & 20.0 & 76.3 & $\mid 305.2$ & 12.1 \\
\hline 1970 & $2,529.0$ & 57.0 & $|526.1|$ & 20.8 & 77.3 & 309.2 & 12.2 \\
\hline 1971 & $2,532.1$ & 58.7 & 541.8 & 21.3 & 79.2 & 316.8 & 12.5 \\
\hline 1972 & $2,567.7$ & 61.9 & 571.3 & 22.2 & 79.2 & 316.8 & 12.3 \\
\hline 1973 & $2,578.9$ & 64.0 & 590.7 & 22.9 & 80.1 & 320.4 & 12.4 \\
\hline 1974 & $2,544.0$ & 64.3 & 593.5 & 23.3 & 80.0 & 320.0 & 12.5 \\
\hline 1975 & $2,518.5$ & 64.3 & 599.0 & 23.7 & 79.4 & 317.6 & 12.6 \\
\hline 1976 & $2,523.7$ & 65.8 & 607.3 & 23.9 & 80.2 & 320.8 & 12.6 \\
\hline 1977 & $2,552.2$ & 68.0 & 627.6 & 24.5 & 80.1 & 320.4 & 12.5 \\
\hline 1978 & $2,564.5$ & 71.9 & 663.6 & 25.8 & 81.3 & 325.2 & 12.6 \\
\hline 1979 & $2,570.5$ & 73.7 & 680.3 & 26.4 & 81.2 & 324.8 & 12.6 \\
\hline 1980 & $2,572.8$ & 75.3 & 695.0 & 27.0 & 81.5 & 326.0 & 12.6 \\
\hline 1981 & $2,574.8$ & 77.4 & 714.4 & 27.2 & 80.9 & 323.6 & 12.5 \\
\hline 1982 & $2,578.7$ & 78.4 & 723.6 & 28.0 & 80.7 & 322.8 & 12.5 \\
\hline 1983 & $2,584.2$ & 79.8 & 736.6 & 28.5 & 81.8 & 327.2 & 12.6 \\
\hline 1984 & $2,594.3$ & 80.7 & 744.9 & 28.7 & 82.8 & 331.2 & 12.7 \\
\hline
\end{tabular}

注） 1964 年以前は三訂日本食品標準成分表に基づく。
表-4 食品別脂質の不飽和度別組成（\%)

\begin{tabular}{|c|c|c|c|c|c|c|c|}
\hline . & 品 & F0 & $\mathrm{F} 1$ & $\mathrm{~F} 2$ & F3 & F 4 & $\geqq F$ \\
\hline $\begin{array}{l}2 \\
3 \\
4 \\
\end{array}$ & 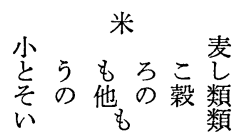 & & $\begin{array}{l}40.0 \\
25.0 \\
29.0 \\
42.0 \\
20.0\end{array}$ & $\begin{array}{l}38 \\
58 \\
57 \\
40 \\
63\end{array}$ & $\begin{array}{l}2.0 \\
7.0 \\
0.0 \\
1.0 \\
2.0\end{array}$ & $\begin{array}{l}0.0 \\
0.0 \\
0.0 \\
0.0 \\
0.0\end{array}$ & $\begin{array}{l}0.0 \\
0.0 \\
0.0\end{array}$ \\
\hline $\begin{array}{r}6 \\
7 \\
8 \\
9 \\
\end{array}$ & 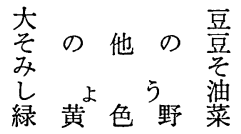 & $\begin{array}{l}16.0 \\
16.0 \\
16.0 \\
16.0 \\
18.0\end{array}$ & $\begin{array}{l}2 \\
5 \\
2 \\
2 \\
2\end{array}$ & $\begin{array}{l}32 \\
51 \\
51 \\
60\end{array}$ & $\begin{array}{l}8.0 \\
8.0 \\
2.0\end{array}$ & $\begin{array}{l}0.0 \\
0.0 \\
0.0 \\
0.0 \\
0.0\end{array}$ & $\begin{array}{l}0 . \\
0 . \\
0 . \\
0 . \\
0 .\end{array}$ \\
\hline & 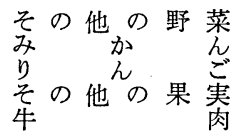 & $\begin{array}{l}10.0 \\
35.0 \\
30.0 \\
10.0 \\
58.0\end{array}$ & $\begin{array}{l}50 . \\
18 . \\
30 . \\
38 . \\
40 .\end{array}$ & 2.0 & $\begin{array}{l}0.0 \\
0.0\end{array}$ & $\begin{array}{l}.0 \\
.0\end{array}$ & 0. \\
\hline 19 & 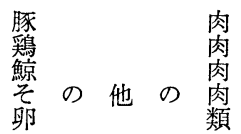 & & $\begin{array}{l}45 \\
53 \\
57 \\
38 \\
37\end{array}$ & $\begin{array}{r}2.0 \\
33.0\end{array}$ & $\begin{array}{l}1.0 \\
1.0 \\
0.0\end{array}$ & $\begin{array}{l}0 \\
0 \\
0 \\
0\end{array}$ & 0. \\
\hline 1 & 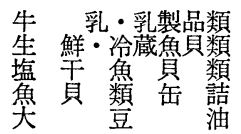 & & $\begin{array}{l}3 \\
4 \\
4 \\
4 \\
2\end{array}$ & $\begin{array}{r}2.0 \\
51.0\end{array}$ & $\begin{array}{l}1.0 \\
8.0\end{array}$ & & $\begin{array}{r}26 . \\
0 .\end{array}$ \\
\hline 28 & 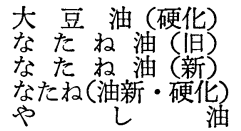 & $\begin{array}{l}0 \\
0 \\
0 \\
0 \\
0\end{array}$ & $\begin{array}{l}6 \\
6 \\
5 \\
8\end{array}$ & $\begin{array}{r}17 \\
26 \\
0 \\
2\end{array}$ & $\begin{array}{r}0.0 \\
7.0 \\
10.0 \\
0.0 \\
0.0\end{array}$ & 0 & 0. \\
\hline $\begin{array}{l}31 \\
32\end{array}$ & 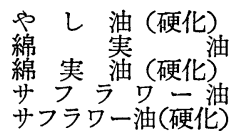 & & & $\begin{array}{r}75 \\
4\end{array}$ & $\begin{array}{l}0.0 \\
0.0 \\
0.0\end{array}$ & 0.0 & 0. \\
\hline $\begin{array}{l}36 \\
37\end{array}$ & ごちも市こし & & 36.0 & & & & \\
\hline 38 & & 25.0 & 71.0 & 4.0 & 0.0 & 0.0 & 0.0 \\
\hline 39 & 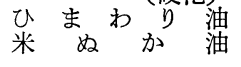 & & & & .0 & & 0. \\
\hline $\begin{array}{l}43 \\
44\end{array}$ & 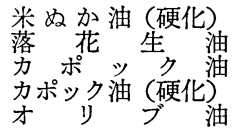 & & & & 0.0 & 0 & 0 . \\
\hline $\begin{array}{l}46 \\
47 \\
48\end{array}$ & $\begin{array}{l}\text { パー公核油 } \\
\text { パーム核油 }(\text { 硬化) } \\
\text { パ } \\
\text { パーム 油 }(\text { 硬化 })\end{array}$ & $\begin{array}{l}99.0 \\
51.0 \\
52.0\end{array}$ & $\begin{array}{r}19.0 \\
1.0 \\
42.0 \\
44.0\end{array}$ & 4.0 & 0.0 & $\begin{array}{l}0.0 \\
0.0 \\
0.0 \\
0.0\end{array}$ & \\
\hline 50 & $\begin{array}{l}\text { その } \\
\text { 類 }\end{array}$ & 40.0 & 40.0 & 20.0 & 0.0 & 0.0 & 0.0 \\
\hline 51 & $\begin{array}{l}\text { その他 } \\
\text { 類 (砳 }\end{array}$ & 45.0 & 48.0 & 7.0 & 0.0 & 0.0 & 0.0 \\
\hline 52 & 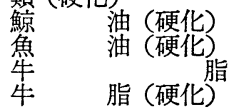 & $\begin{array}{l}58.0 \\
59.0\end{array}$ & 41.0 & $\begin{array}{l}2.0 \\
0.0\end{array}$ & \begin{tabular}{r|}
11.0 \\
0.0 \\
0.0 \\
0.0
\end{tabular} & 0.0 & 0.0 \\
\hline 56 & 脂 (硬化) & $\begin{array}{l}44.0 \\
47.0\end{array}$ & $\begin{array}{l}45.0 \\
51.0\end{array}$ & $\begin{array}{l}9.0 \\
2.0\end{array}$ & $\begin{array}{l}2.0 \\
0.0\end{array}$ & & 0. \\
\hline 58 & & 59.0 & 38.0 & 2.0 & 1.0 & 0.0 & 0.0 \\
\hline & 類 (硬化) & 0.0 & 40. & 0.0 & 0.0 & 0.0 & 0.0 \\
\hline
\end{tabular}

（注）なたね油については, 1975 年以降は（新）を, それ以 前は（旧）を適用した。 
表-5 供給脂質の不飽和度別組成 (\%) の推移

\begin{tabular}{|c|c|c|c|c|c|c|}
\hline 年次 & Fo & $\mathrm{F} 1$ & $\mathrm{~F} 2$ & F3 & $\mathrm{F} 4$ & $\geqq \mathrm{~F} 5$ \\
\hline 1960 & 27.4 & 37.7 & 29.1 & 3.4 & 0.5 & 1.9 \\
\hline 1961 & 27.5 & 38.0 & 28.4 & 3.4 & 0.6 & 2.1 \\
\hline 1962 & 28.5 & 37.8 & 28.1 & 3.3 & 0.4 & 1.9 \\
\hline 1963 & 29.3 & 35.5 & 30.0 & 3.1 & 0.4 & 1.7 \\
\hline 1964 & 29.3 & 35.7 & 30.3 & 3.0 & 0.3 & 1.3 \\
\hline 1965 & 28.7 & 36.5 & 29.2 & 3.1 & 0.5 & 2.0 \\
\hline 1966 & 29.7 & 36.5 & 28.4 & 3.1 & 0.4 & 1.8 \\
\hline 1967 & 29.7 & 36.3 & 28.8 & 3.0 & 0.4 & 1.7 \\
\hline 1968 & 29.6 & 36.9 & 28.3 & 3.1 & 0.4 & 1.7 \\
\hline 1969 & 30.2 & 36.9 & 27.9 & 3.1 & 0.4 & 1.5 \\
\hline 1970 & 28.6 & 35.8 & 30.3 & 3.6 & 0.3 & 1.4 \\
\hline 1971 & 30.4 & 37.6 & 27.0 & 3.1 & 0.4 & 1.5 \\
\hline 1972 & 30.4 & 38.1 & 26.5 & 3.2 & 0.4 & 1.5 \\
\hline 1973 & 30.6 & 38.9 & 25.5 & 3.2 & 0.4 & 1.5 \\
\hline 1974 & 29.4 & 39.2 & 26.2 & 3.3 & 0.4 & 1.5 \\
\hline 1975 & 29.5 & 38.6 & 26.2 & 3.6 & 0.4 & 1.7 \\
\hline 1976 & 30.3 & 38.3 & 25.8 & 3.6 & 0.4 & 1.6 \\
\hline 1977 & 30.3 & 38.4 & 25.5 & 3.5 & 0.4 & 1.9 \\
\hline 1978 & 30.2 & 38.5 & 25.4 & 3.5 & 0.5 & 2.0 \\
\hline 1979 & 29.7 & 39.2 & 25.2 & 3.6 & 0.4 & 1.9 \\
\hline 1980 & 29.9 & 39.2 & 25.2 & 3.5 & 0.4 & 1.8 \\
\hline 1981 & 29.4 & 39.4 & 25.4 & 3.7 & 0.4 & 1.7 \\
\hline 1982 & 29.4 & 39.2 & 25.8 & 3.7 & 0.4 & 1.6 \\
\hline 1983 & 29.4 & 39.0 & 25.8 & 3.7 & 0.4 & 1.7 \\
\hline 1984 & 29.0 & 39.6 & 25.7 & 3.7 & 0.4 & 1.7 \\
\hline
\end{tabular}

注） 1964 年以前は三訂日本食品標準成分表に基づく。

(イコサノイド）の影響を考えた場合は， $\omega-6 / \omega-3$ の割 合をみた方がよいと思われる。最近の $\mathrm{F} 2 /(\mathrm{F} 3+\mathrm{F} 4+$ $\geqq \mathrm{F} 5)=4.5,(\mathrm{~F} 2+\mathrm{F} 4) /(\mathrm{F} 3+\geqq \mathrm{F} 5)=4.8$ で, F 2/ F 3 の場合と同様にほぼ一定しているが，1965 年から時 系列的にみた場合はやや減少傾向である。

最近リノール酸の摂取量が多くなり， $\alpha$ リリノレン酸の 掑取量が相対的に低くなっているので $\alpha$-リノレン酸の 捸取量を増加すべきであるとの説7)があるが，栄養学上 リノール酸に対する $\propto$ リリレン酸の最適割合について は今後の検討課題であろう。図-4〜図-6 から分かるよ うに $\omega-6 / \omega-3$ の割合は一定ないしやや減少傾向, すな わち $\omega-6$ 系に対して $\omega-3$ 系は一定ないしやや增加傾向 にあり, P/S と共にバランスがとれており, あまり問題 ないと思われる。

\section{3 結論}

1) 脂質エネルギー比率は増加傾向にある。

2) $\mathrm{P} / \mathrm{S}$ は 1.1/1 でほぼ一定している。

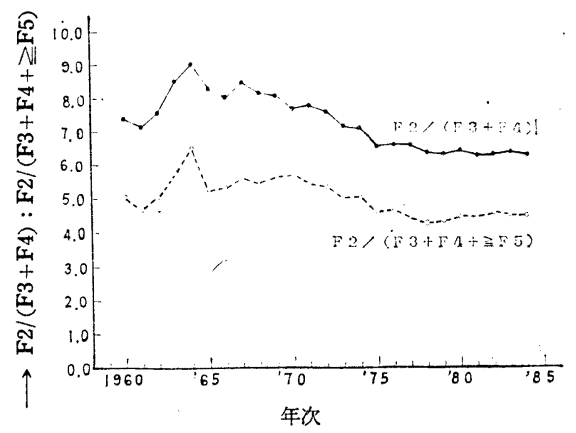

図-5 供給脂質の $\mathrm{F} 2 /(\mathrm{F} 3+\mathrm{F} 4), \mathrm{F} 2 /(\mathrm{F} 3+\mathrm{F} 4+\geqq \mathrm{F} 5)$ の推移

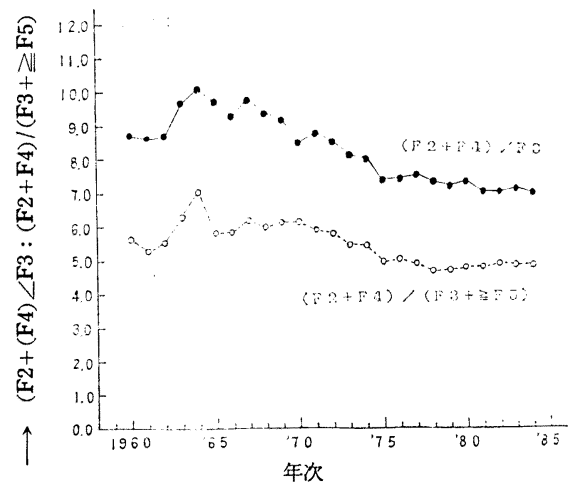

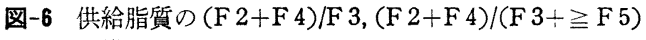
の推移

3 ）多不飽和脂肪酸の最近の F $2 / \mathrm{F} 3$ の割合は約 $7.0, \omega-6$ 系 $/ \omega-3$ 系の割合は 4.8 4.9 で, ほぼ一定し ているが, 1965 年から時系列的にみるとやや減少傾向 にあり， $\omega-6$ 系 $/ \omega-3$ 系多不飽和脂肪酸の割合に関して はあまり問題ないと思われる。

$$
\text { 文 昭和 } 62 \text { 年 } 5 \text { 月 } 8 \text { 日受理) }
$$

1) 奥山治美, 日本油化学協会, 関西支部, 第 17 回油脂食品 部会講演会 (於大阪) (1987 年 1 月 27 日)

2) 長倉 稔, 吉富和彦, 油化学, 33, 388 (1984)

3) 農林水産省大臣官房調査課編, 食料需給表 (昭和 59 年 度), (財) 農林統計協会刊, (1986 年)

4) 農林省食品流通局編, 「製油要覧」, (社) 日本油脂協会刊, 1964 年 1978 年

5）農林水産省食品油脂課編, 「我が国の油脂事情」，1977年 $\sim 1986$ 年

6) 厚生省保健医療局健康增進栄養課編, 第 3 次改訂日本人 の栄養所要量, 第一出版刊, (1986 年)

7) 奥山治美, 油化学 (生化学) 講演会 (於東京) (1987 年 5 月 25 日) 